\title{
Innovative Management of College Students in the New Media Era
}

\author{
Dan Wang \\ Jilin Normal University, Haifeng Street, Siping City, Jilin Province, China, 136000 \\ 1172995236@qq.com
}

Keywords: New media, Management of college students, Innovation.

\begin{abstract}
The new media are increasingly affecting and changing college students' learning, life style and values. The widely use of new media also brings new opportunities and challenges to the management of college students. College student educators should grasp this new opportunity, make full use of the advantages of new media in college students' management, and innovate the way of college students' management. College student educators should make new media as an effective carrier for enhancing the actual effect of college students' management.
\end{abstract}

\section{Introduction}

New media era means a time that new technical support system appeared in the media form. It uses digital technology, network technology and mobile technology; provide users with all kinds of information form through the Internet, cell phones, computers, etc. In this requirement of the times, a new pattern of information in which media integrated appears. At the same time, college students' study habits, thinking modes and the pace of life are changing, which requires the traditional model of college students' management should be changed, and through practice, college student educators should explore a new model which adapt the management of college students in new media environment, to meet the demand of the times and educate better college students.

\section{Effects of the Rapid Development of New Media on Management of College Students}

\section{New media has brought new opportunities for college students' management}

Fast and convenient service of new media information spread enhances the efficiency of college students' management. The management of college students can make use of the characteristic of fast and convenient service of new media in the field of information spread, through websites, cell phone newspapers, e-magazines, microblogging and other forms provide the contents which are conducive to college students' healthy growth in current society, and transfer positive energy to college students. Meanwhile, the management of college students can also make use of the characteristic of diversification of new media information publishing. College students use less time to get first-hand information. The narrative mode of information has changed from the unifaciality of traditional media to multi-angle, multi-side, which is more helpful for college students to arouse their interests in obtaining information [1]. The transmission of this kind of information has strong pertinence, after college student educators' screening and sorting, this kind of information can be timely and accurately transmitted in the maximum range among college students. For example, a lot of things which are going on around us or latest news from the Internet, all of these could make college students know through the spreading of new media. New media have a larger influence and could make more people know what happened; the traditional media cannot be compared with those advantages of new media. Take advantages of new media, the efficiency of carrying out work on college students' management will be greatly improved.

The interaction of information transmission in new media provides a communication platform for college students' management. In contemporary society, college students use new media to express their true feelings, even self-catharsis, they create their personal zone on the Internet. College student educators can use new media technology, through browsing moments, Qzone, reading twitter or WeChat, to more directly, deeply understand college students' ideological 
trend and psychological state, and carry out positive guidance or communicate with them in time, solve college students' ideological problems. For some introverted college students who are not good at communicating with other people, college student educators can also anonymous communicate with them over the network, help these college students with their problems. Using network to communicate with these college students, college student educators could solve the problems that these college students' inability to communicate with their teachers. In the meantime, using network to communicate with college students help teachers discover more problems about them. The interactivity of new media provides a variety of ways and interactive as well as equal communication platform for college students' management, which also open up a new way for the development of college students' management. How to use new media to promote school management work is an issue to be solved urgently [2].

The diversification of new media information spread channels expands the scope of college students' management work. The basic carriers of developing college students' management work usually include classes, dormitories, school societies and student councils. Under the background of new media, a new management work of college students-- network carrier is widely used. College student educators can make use of the advantages of new media technology, such as new media technology includes too much information, convenient information transmission, various forms, etc, to expand activity space of college students' management work, break the relatively fixed, single state of traditional forms of work. Through the ways of issuing opinions on the forums or blogging about something to spread positive energy, college student educators can also carry out ideological and political education for college students; strengthen monitoring of college students' ideology, master college students' ideological trend at any time. New media greatly expand the space of college students' management, open up a new position for college students' management work.

\section{The management of college students faces new challenges under the new media environment}

Wide application of new media technology increases the difficulty of college students' management. With the development and application of new media technology, college students become more and more comfortable using different carriers or different kind of ways to send information or communicate with other people, especially post-90s college students, who are keener on these new things, therefore, taobao shoppers, micro bloggers and other groups emerged. Some college students carry their cell phones all day, and if not, they will feel fidgety. However, if college students use their cell phones to communicate with other people through mobile phone software WeChat or Microblog during classes, who will seriously cause classroom disruptions. All kinds of different realistic reflections from college students, which present new difficulties to the management of college students. Meanwhile, the new media platform changes the educational and life environments of college students, which makes their educational and life environments extend from realistic to virtual, and this kind of life surroundings is more complex[3]. All of these changes present new challenges for the management of college students.

The virtuality of new media brings new tests to the management of college students. College students in virtual world which constructed by new media, who often confuse the real world with the virtual world. Most college students have been used to communicating with other people by using anonymous or pseudonymous ways in virtual world, who consider that in these words unconstrained environment; they can say whatever they want or do whatever they want. However, some college students are too obsessed that they choose skip or truant a lot of classes, even stay in their dormitories all day long. At the same time, some college students develop psychological problems; they are confused or fearful with the real world, even pessimistic. This kind of virtualization of living space has greatly affected the growth of college students; it also brings new challenges to college students' management.

The diversity of information in new media brings challenges to college students' management. On the background of new media, because information transmission is more convenient and arbitrary, some social negative information, such as pornography, violence and other affairs will instill into college students' mind through information networks, especially some 
information which is not consistent with socialist core values that our country advocated, but widely spreads to college students via new media. This kind of negative information has severely bad impact on the college students' growth of physical and mental health. College students are at a critical stage of forming the values. If college students receive this kind of harmful information, which will directly affects the formation of their values, personality and morality, and increase the difficulty to college student educators' educational guidance.

\section{Coping Strategies on College Students' Management that New Media are widely used}

\section{Change ideas; use new media technology to realize modern management of college students}

New media has played an important role on the management of college students, college student educators should make full use of new media, come up with new work methods, improve the actual management effect, carry out college student jobs by various methods. If college student educators want to become college students' life mentors or intimate friends, they should have keen senses of times and insight, update the concept of educating people constantly, meet the needs of times, use new media technology to carry out college students' management flexibly. For instance, QQ, microblog, WeChat or other communication tools should be introduced into college students' management, for college student educators adopt modern means to solve college students' problems better. By interacting with college students on the Internet, college student educators could promote communication with them. In these ways, college student educators not only can know more about college students' situation, but also compensate for the deficiencies in jobs, to meet the requirements of paying attention to each student.

\section{Meet the needs, use new media to build a new platform for the management of college students}

College student educators can make new media as a tool, to grasp college students' ideological trends more readily. In the meantime, college student educators can also convey information to their students more accurately via new media. Facing some positive ideas in society, college student educators are able to make these ideas widely publicized or popularized to college students via new media, in order to make young college students establish proper view of values, and build a new position of ideological and political work. In daily college students' management working process, Internet can be regarded as a learning tool, through which college students can learn some extra-curricular knowledge, explore the unknown fields and acquire more knowledge. Based on the traditional working style, college student educators should make the best use of new media; make traditional ways and modern ways melded, so as to learn from each. College student educators should actively take good advantage of superiority resources of new media; build a new platform for college students' management.

Guide college students, strengthen college students' cultivation on media literacy, enrich college students' college life

Media literacy education is an education to train college students to understand correctly and share constructively mass media resources. Through media literacy education, college student educators should cultivate college students with proper media criticism ability, make college students use media resources improve themselves, and participate in the development of society [4]. With the continuous development of new media, some phenomena, such as Internet addiction disorder, mobile phone addiction, appeared among college students. These phenomena have already aroused concerns of college student educators. In the management of college students, college student educators should try their best to promote college students' new media literacy, make college students form correct concepts. College student teachers should guide their students understand the new media, make good use of new media to serve for their own studies and life. For example, in terms of enriching carrier of campus culture, college students can enrich their university campus life by bringing in new media campus forums, campus microblogging and other various 
forms on the foundation of original billboards, display boards or posters. College student educators can also actively carry out public opinion analysis on the Internet, carry forward positive thoughts, and provide correct guidance for college students. College students should construct core values in conversations and discussions, and meet the goal of ideological education.

\section{Summary}

The arrival of new media era brings opportunities and challenges to the management of college students. College student educators should seize opportunities, meet the challenges, grasp the pulse of the times, fully understand and take good advantage of new media, rationally use modern information means, expand educational ways of the management of college students, improve working methods, create a new normal management of college students on the background of new media era.

\section{References}

[1] En-Lai Jiang, The ideological and political education of college students in new media environment, [J] Study on the ideological and political education. 6 (2009) 54-56.

[2] Yi Zhou, A brief discussion on the management of students in new media environment, [J] Media education. 5 (2012) 231-232.

[3] Jian Zhao, The principle and boundary of student work in new media environment, [J] College counselors. 1 (2012) 15-19.

[4] Di Wang, New media offer new challenges for post-90s college students' ideological and political education, [J] Study on ideological education. 1 (2010) 71-74. 